\title{
WORK ALLOCATION IN COMPLEX PRODUCTION PROCESSES: A METHODOLOGY FOR DECISION SUPPORT
}

\author{
Adriana Marotti de Mello \\ School of Economics, Business and Accounting at the University of São Paulo \\ adriana.marotti@usp.br \\ Roberto Marx \\ Polytechnic School, University of São Paulo \\ robemarx@usp.br \\ Mauro Zilbovicius \\ Polytechnic School - University of São Paulo \\ mzilbovi@usp.br
}

\begin{abstract}
This article presents the development of a Methodology of Decision Support for Work Allocation in complex production processes. It is known that this decision is frequently taken empirically and that the methodologies available to support it are few and restricted in terms of its conceptual basis. The study of Times and Motion is one of these methodologies, but its applicability is restricted in cases of more complex production processes. The method presented here was developed as a result of a project coordinated by the authors, on demand by a large Brazilian petrochemical company. An Action Research based approach was used to develop the method, based on the generation of alternative scenarios offering different possibilities for work allocation. This paper aims to contribute to the literature on the theme, starting from a premise that it is necessary to develop a method that organizes information and, as much as possible, makes explicit the premises and the consequences that decisions on work allocation might cause.
\end{abstract}

Keywords: Work allocation, Complex Operations, Scenarios

\section{INTRODUCTION}

This article presents the development of a Methodology of Decision Support for Work Allocation in complex production processes. It is known that this decision is frequently taken empirically and that the methodologies available to support it are few and restricted in terms of its conceptual basis. The study of Time and Motion is one of these methodologies, but its applicability is restricted in cases of more complex production processes, as is the case, for example, of continuous flow operations intensively supported by automation technologies (Woodward, 1965).

The method presented here was developed as a result of a project coordinated by the authors, on de- mand by a large Brazilian petrochemical company, in one of its plants operating in Brazil. The work consisted in providing technical-conceptual support to help in the analysis of the process that may induce modification of work allocation in the operational area of the target plant.

Since the late 1980s, the company in question has been under a restructuring process, in order to improve its financial and operational performance. Within this context, aiming to reduce labor costs, measures such as the increase in industrial automation, outsourcing of activities and reduction in operational staff were taken, using as parameter the comparison with similar plants in Brazil and abroad. The decision process was conducted empirically, based 
on the managers' experience and on several historical and conjuncture variables that have influenced the decision.

The company in question is a continuous processes industry, in which the technological (indivisibility of the process, high level of integration of equipments, centralization of operations control) organizational (non-dependence between work pace and productivity) and economical (fixed labor costs) characteristics and their complexity (interdependence of the operation variables, symbolic character of process variables, random city and unpredictability of operation) have implications for the organization and the type of work required, specially for the operational area (Woodward, 1965, Khurana, 1999), which makes the classical methodology for work allocation - the studies of Times and Motion - not applicable to this case (Zarifian, 1994). So, a question arises: Which method for support decision on work allocation would be suitable to complex processes?

In order to answer this question, this work therefore attempts to propose a method to support work allocation decision in Complex Operations (such as the continuous processes operations), and that could be also used as a planning tool for the organization. To develop it, the following premises were used as starting points:

The decision over work allocation is generally a decision of political nature, since different conflicting interests - both within and outside the company are affected by it. Nevertheless, the application of operation management concepts, techniques and tools may contribute to the decision process, so that a consistent framework may be reached concerning the number of people required for a certain industrial operation, expliciting premises and consequences of each feasible solution.

There is not a method universally accepted to deal with the work allocation issue. The method to be employed depends on analysis of the productive process and on the identification of the factors that interfere in the relation among technology, productive system and the role played by operators in the process.

Also, there is no "optimal" decision over the work allocation issue. It cannot be ignored that this decision is not just technically feasible and that it interferes in the interests articulated within (workers, managerial staff) and outside (unions, service and product suppliers, governmental institutions, shareholders, etc) the organization, interests that gain or loose as the personnel contingent increases or decreases.

Based on these premises, an original methodology was generated, specially developed for the case in question, but which, as the work will attempt to demonstrate, may be replicated to other companies, with or without complex processes, in the industrial or services sector.

The method proposed is based on the generation of different alternative scenarios that show distinct possibilities for manpower allocation. Each scenario is oriented by certain premises and assessed by a set of significant efficiency indicators for the company.

Therefore, the present article is organized as follows: in the following section, a discussion of the theme is made from a bibliographical review conducted on the subject; then, the methodology used is presented. Next, an explanation is provided for the scenarios concept and its application for work allocation and, finally, in the last section, the conclusions, merits and restrictions of the methodology proposed are presented.

\section{DISCUSSION}

Characteristics of Continuous Processes and their Implications for Work Organization

The continuous processes industry is characterised by the continuity of its production. This type of process is found in different industrial sectors, as for example petrochemical, steel, paper and pulp and electric power generation. Technological and economic characteristics and complexity of this type of process have important implications for the work organisation in these industries, especially in the operational area (Woodward, 1965, Khurana, 1999).

From the technological point of view, continuous process is characterized by (Toledo, Ferro and Truzzi, 1986):

Raw material indivisibility: since the productive process is composed of a sequence of chemical reactions and unit operations, most of the times it is not possible to distinguish inputs from final products. Thus, the relation of the worker with the raw material and the product is totally distinct from other types of industries.

High level of integration among equipments: instead of isolated machinery performing different 
operations, a continuous process is characterized by a sequence of equipments interlinked and interdependent, resulting in low flexibility and interchangeability of equipments. The process is not, therefore, formed by discrete operations, but by process phases.

Greater possibility of centralizing the control of processes: since the interaction among the operators and the product is reduced and nearly all of it is subject to intermediation of equipments, process control does not mean the control of the tasks performed by workers, but the control of equipments.

Besides these characteristics, a continuous process is usually characterized by a high level of automation and the use of computerised integrated control systems, which implies specific interactions among the workers and the task to be conducted: the main task of the operators thus becomes monitoring and controlling the process variables, aiming to maintain operational continuity, correcting occasional deviations and dealing with unpredictable flaws and variability in equipment performance (Buchanan and Bessant, 1985).

The economic characteristics that have implications for the work organization are (Toledo, Ferro and Truzzi, 1986, Zarifian, 1994):

No direct dependence between the work pace and productivity: productivity is dependent on the operational output of the equipments, and not on the pace of human work. From this characteristic follows the assumption that Motion and Times approach is not a suitable tool to work allocation decision in this case since human pace is not directly linked to productivity.

Capital-intensive industrial plants and fixed labor costs: the continuous process industry tends to require high investments in equipments, and the labor cost does not vary according to the volume produced, and may be considered fixed. Furthermore, labor cost, as compared to the opportunity cost of the capital invested in equipments is very small.

Given its technological characteristics - interdependence of its variables, process indivisibilidity, randomicity and unpredictability, symbolic character of the operation (codification and abstraction) - the work operation and organization in continuous processes may be considered as complex. The operation of a complex process requires a different work organization and a different operator profile compared to other types of operation (Khurana, 1999). The type of task performed by workers in a continuous and complex process significantly differs from the work developed in a manufacturing process: the operators work is basically monitoring, controlling process and equipment parameters, analyzing and taking action about deviations identified in relation to a specified condition known by the operator. One may argue that automated systems are also designed for this function, but they are not always able to perform it without some human interaction. In some situations, the operator is required to take full control of part of the operations and to conduct one or more maneuvers independently of the technology.

The perception to distinguish abnormal situations ("events") from trivial situations and the course of action to be taken in each case is an essential task for operators of this type of process. He/She must be able to make decisions about each task conducted, which requires relatively wide knowledge and an deep understanding of the whole process, attributes that are occasionally required, at a smaller scale, in operations characterized by discrete production processes (Daniellou, 1995).

Moreover, since the process and, therefore, the activities associated to it are indivisible and interdependent, the work is eminently collective, conducted by teams and not by an individual. Thus, the communication among operators and the formation of teams thus become essential.

The work allocation method using the study of Times and Motion emerged in the works conducted by Taylor (1947) and well explained in details by Barnes (1980). This method, does not take into consideration other factors that might affect work allocation, although it is still used nowadays to support this decision in different environments - for example, Yeh, Lan and Lai (2005) and Knapp and Mahajan (1998) for discrete manufacturing processes and Brennan and Orwig (2000) for engineering consulting companies.

The indivisibility and interdependence of tasks and the dissociation between human work pace and the process productivity make Times and Motion method (from now on T\&M) not suitable to complex and automated operations (Zarifian, 1994). The application of T\&M supposes the decomposition of the work into simple standardized tasks and with standardized execution time. The work in the operation of a continuous process cannot be divided and it cannot have its time 
standardized, either, due to its much more intellectualized character (monitoring, control and adjustment of parameters) and its imprevisibility (for example, it is very difficult to know when there will be a failure in a piece of equipment and how long will it last). Also, the T\&M method fails to consider the collective character of the work in a continuous process, as it only analyzes the technical issue of the work and does not consider the capacity - and the necessity - for cooperation among workers (Zarifian, 1994).

It is also relevant to point out that, for T\&M application, there is a fundamental differentiation between productive and non-productive times. This distinction lies basically between the time in which the worker executes an operational task and the time in which he/she does not. In the case of continuous and intensely automated processes, this distinction makes little sense. How to identify productive and non-productive time in process monitoring activities?

Nevertheless, in the absence of alternative methods that support work allocation and that take into consideration the continuous process complexity and characteristics, many companies have attempted to use eminently quantitative methods (based on T\&M) of work allocation, with less than encouraging results. Most of these decisions, therefore, have still been made based on empirical criteria and on an ad-hoc basis. The next section attempts to develop the contribution of the present work, attempting to fulfill this conceptual and practical gap.

The nature of managerial decision: lessons according to Henry Mintzberg work

Henry Mintzberg is a well known and respected author who have studied for many years the nature of managers work. He defends the point of view that management is not a sicence although managers usually utilize science as a source of information for their decisions. But they use a miryad of other sources, which includes intuititve perceptions, management fashions, practical experience (tacit knowledge), visions (including the strategic one) as sources for their actions and decisions (Mintzberg, 2009).
The problem of work allocation is a typical manager decision and for that reason, according to Mintzberg approach, a framework that could help managers to organize the variables that interphere in this problem may become a realistic and pragmatic approach to facilitate this decision making process.

The importance of Mintzberg approach is that it stresses the importance of combining organization analisys with the political, economical and symbolical point of view in trying to understand and explain the mangers decision process. It also recognize the limitations of both qualitative and quantitative data if taking into account in a narrow and separated domains.

In the next section the authors will present all the main factors that may have an influence over the problem of work allocation. Next, all those factors, including the quantitative (or hard data in Mintzberg words) and qualitative (soft data) will be taken into account in proposing a framework that tries to organize and add value to the process of decision making.

\section{Work allocation: factors to be considered}

It is understood that different factors affect work allocation (see figure 1, as follows). These are:

- The economic and commercial context in which the company is inserted and its development strategy.

- Social and demographic dimension - operators' characteristics: formation, individual and collective competencies, experience/ professional trajectory, time at the company and health situation.

- The production and its organization, including work organization (criteria for dividing and coordinating the activities).

- Technical dimension - involves both the production processes themselves and the products (quality and diversity criteria).

- Investments in the existing installations or foreseen for new installations.

- Laws and regulations that may be related to the work and its organization. 
Figure 1 - Factors affecting Manpower Allocation

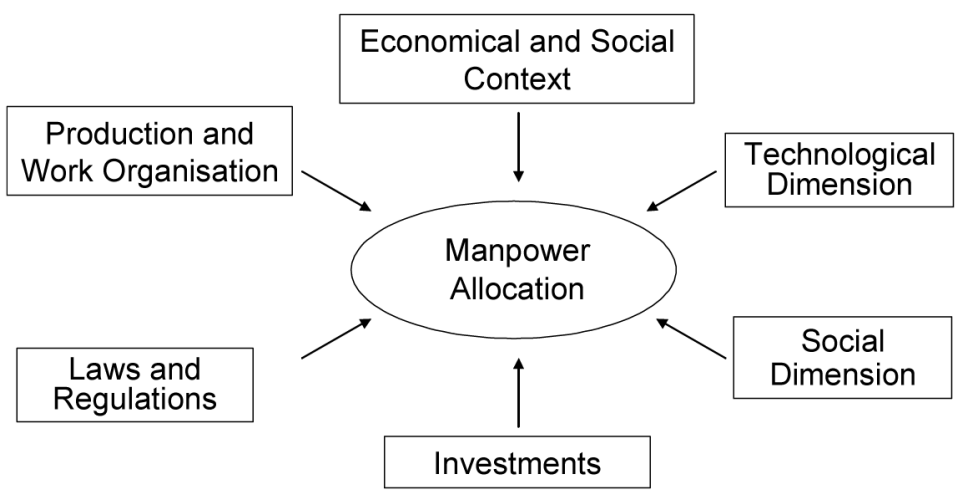

Source: Created by authors

Besides, the decision on work allocation must be made under consideration and explicitation of the different perspectives that usually influence it at a larger or at a smaller scale:

- The company point of view, including the different managerial views

- Workers' point of view, including their union representatives.

- Technical point of view, which is, deriving from the application of principles and methodologies conceptually adequate, validated and available to help decision-making on work allocation.

- Other points of view: analysis of competitors, benchmarking related to installations and similar operations, tradition and cultural aspects, characteristics of the industry.

Work allocation necessarily undergoes a discussion which has to consider and make explicit these different points of view. And why is it important to consider it? Without this discussion and the explanation of different points of view, there is a great risk of choosing a solution with results inferior to the ones desired or even of an unfeasible solution, since possibly aspects relative to the work, to workers' demands, intermediate level personnel in the hierarchy, union, organization interests or of part of it failed to be considered.

\section{Use of Scenarios as a Planning Tool}

A Scenario can be defined as a mental model accepted and shared with the world outside, involving descriptions of a possible future with internal consistency, that is, the outcome of a plausible trajectory (Van der Heijden, 1996).

The use of scenarios comes from Strategic Planning, originated especially at Shell that developed a method for planning future actions based on experts opinions from different knowledge areas. These scenarios expressed future possibilities, with a certain degree of uncertainty, but based on a coherent logic (Van der Heijden, 1996).

In this work, the use of scenarios does not intend a specific representation of the future, but to simulate a deep and clear understanding of the impact of work allocation in indicators that company management considers critical from diverse - and often contradictory - points of view, like productivity (production per time interval), quality (errors in ppm), safety (accidents), costs, political impacts, risk, etc. Thus, the choice of impact indicators becomes a critical point in this method and the criteria for choosing them, must necessarily contemplate the previously discussed factors (such as investment, social dimension, etc). Every scenario should be evaluated against the same indicators, previously defined.

The scenarios methodology, as discussed before, is based on the assumption that work allocation is, by nature, a political decision, made under consideration of different perspectives, as shown in Figure 1 , and different standpoints, from the company, the workers and union perspectives, technical, social and legal constraints. The methodology here proposed attempts to consider all these aspects, by the use of different premises and indicators. 
The premises reflect current (and future) status of work conditions, making explicit the influence of the different factors that impact on work allocation (as shown in figure 1), regarding technology, organizational structure and knowledge management. They define the contour conditions - of technological and organizational nature. Also, the different levels of premises and the possibility of changing each of them were identified.

The indicators express the performance of the scenario in relation to factors of the interest of the organization. It aims to represent the impact and possible future developments of changing manpower in different factors that are relevant for the management of the operation. These indicators have to be built collectively, by management and workers, and should express the criteria by means of which the scenarios would be developed and assessed.

\section{METHODOLOGY}

In this work, the option was for the Action Research (AR) methodology, which is the use of an academic and scientific view to study the resolution of problems of an organization together with those directly involved in the subject. AR works through a cyclical four-step process of consciously and deliberately: planning, taking action and evaluating the action, leading to future planning. (Coughlan and Coghlan, 2002).

This paper derives from a project developed by the team of researchers on demand of a large Brazilian company in the petrochemical sector, which needed support to work allocation decision for the operational area of one of its plants.

Coughlan and Coughlan (2002) identify six main steps in developing an AR project:

1. Data Gathering, through active invovlment in the company daily operations related to the research project. Data can be gathered in either formal (meetings, interviews) or informal ways (coffee break talks), through observation or direct inquiry.

2. Data feed-back: The data collect in step 1, is presented to the company to check validity

3. Data Analysis: In a collaborative manner, researcher and company teams discuss and analyse the data.

4. Action Planning: Reaseach and Company members (usually, a steering team) discuss a plan to implement what needs to be done in order to solve the research problem. In this phase, all possible pitfalls to the success of the plan should be addressed, such as internal resistance to plan, and managerial commitment.

5. Implementation of the plan, by the company

6. Evaluation: Involves reflection on the outcomes of the action, both intended and unintended. This step is key to learn from the mistakes, and to prepare the next cycle of planning and action.

The project development was conducted from the premise that, in order to contemplate all elements interfering in the work allocation process and considering specific characteristics of the company and of the productive process, it was necessary to develop an original method. So, the aim of the project was the production of scenarios for work allocation using a methodology likely to be replicated.

As expected results, the following were defined:

- The establishment of key indicators associated to relevant aspects for work allocation, allowing the assessment of scenarios;

- The building of coherent and consistent alternative scenarios assessed by these indicators;

- The development of a method, which might be replicated at any moment, at any plant in the company or in other organizations.

The building of scenarios was the main methodological element utilized. The scenarios were defined as situations in which different elements interfere in the work process, including technological, organizational, social, political and strategic factors. These factors are interlinked, building a certain logic that structures the organization of work. From the understanding of this logic and the analysis of the different factors, based on indicators developed to express the performance of the scenario in relation to factors of the organization interest, it was possible to build different new scenarios from the initial one, which represent the current situation of the plant studied.

For the development of this methodology, it is fundamental to consider all the aspects of the issue, be they technological, organizational or of some other nature. All of the points of view of the agents involved must be known and analyzed, including managers, operators, support areas, corporative level and unions. These visions were collected and analyzed to identify the prevailing points of view and 
premises in relation to production and work process. As indicated by the Theory of Organizations (Morgan, 1997), these agents usually hold positions that might represent interests of groups inside the organization. This aspect cannot be ignored, as neither can the fact that work allocation, particularly, is subject to political character interferences, that is, it reflects power strategies and interests confrontation from the different agents involved. Nevertheless, the methodology employed, when taking the production and work process as the central object, focusing at work allocation, has as a premise to consider only points of view referring strictly to this central object, even if the origin of each formulation - or even information - may have derived from premises of political or even ideological nature.

The action research process lasted approximately five months, along which part of the researchers team followed the work routine of the company full time, and it was developed in five phases, as follows:

Phase I - Delineation of the Current Scenario - corresponding to the Data Gathering and Data Feedback phases, defined by Coughlan and Coughlan (2002)

Phase II - Building of Scenarios

Phase III - Analysis of Alternative Scenarios

Phase IV - Revision of Scenarios

Phase V - Presentation of Results

Phases II, III and IV were developed in three different sequential cycles, as will be made explicit further on, so that the development of consistent and coherent scenarios could be reached. These phases correspond to Coughlan and Coughlan's (2002) Action Research Data Analysis, Planning, Implementation and Evaluation Phases.

\section{Phase I - Delineation of the Current Scenario}

In this phase, the aim was to get familiar with the work routine of the company and to collect the largest possible volume of information concerning the production and work process, in order to have a good understanding of the current scenario.

Then, in order to deepen the understanding of work in the operational area of the plant, workshops with operators were done. These workshops had the important role of making visible the strategies and courses of action developed by operators to con- duct their activities. The literature and experience showed that many times the managerial level of the companies, given the position occupied in the organizational structure, has no knowledge of these elements which, by nature, are key constituents of the way the work is effectively conducted.

So, an initial scenario of the current situation was developed. This scenario was exhaustively assessed with a group of different managers of the company, in order to improve it, specially regarding to the indicators used to assess it.

\section{Phase II - Building of Alternative Scenarios}

After finishing phase I, the building of new different scenarios was started. Each scenario has a driver or conductor for its development, that is, an opportunity for improvement identified in the previous phase.

A recursive test process of the scenarios was established in relation to the indicators chosen in phase I, collection of new information to clear doubts or obscure points, possible change and refinement of indicators besides the identification of premises not previously perceived. A first impact assessment exercise was conducted on the changes caused on indicators by the scenarios.

\section{Phase III - Analysis of Scenarios}

The current scenario, as well as a first version of the scenarios developed, was presented to the managers of the company, for identification of inconsistencies and possible assessment errors.

As a result, there was a general assessment of the managers' reaction to the scenarios and to the indicators used, which allowed for some of the scenarios and for refining the set of indicators.

\section{Phase IV - Revision of Scenarios}

As a result of the previous phase, the project team started to revise the scenarios developed, implementing the agenda for collecting new relevant information. Fundamentally, attention was turned to observing operators', managers' and technicians' work, coupled to the new consultation to the documented data.

After collecting and analyzing the new data, phase II was resumed for developing new scenarios, necessarily more consistent in relation to the ones pre- 
viously produced, configuring a recurrent process between phases II, III and IV, until the scenarios developed were satisfactory in terms of consistency of the impacts in relation to the indicators, and to the premises that were chosen to be kept or altered.

\section{Phase V-Presentation of Results}

Finally, phase $\mathrm{V}$ was that of presenting the final set of premises, indicators and scenarios, with the corresponding justifications and analyses, in terms of impacts caused and the benefit/ cost relationship of the alterations in relation to the current scenario.

\section{The Scenario Concept And Its Application For Work Allocation Decision}

The building of scenarios is the main axis of the method to support the work allocation decision developed here. As already discussed, a scenario could be defined as a representation of situations where different elements interfering in the work process are interlinked building a certain logic which structures the organization of the work processes.

From the understanding of this logic and the analysis of the different factors, it is possible to build several new scenarios from the initial scenario, which represents the current situation of the company. These scenarios can then be analyzed in terms of the changes in the indicators chosen in relation to the current situation.

Thus, the decision makers concerned with work allocation could conduct sensitivity analyses of the current scenario as related to the changes likely to be introduced, verifying their impacts and converging in relation to more advantageous scenarios according to the goals of the company.

Example of the scenario concept applied to a fictitious company

Due to a secrecy commitment between the project team and the company, the next section will present an example of the application of the method in a plant from a fictitious company named " $X$ ", operating a continuous process in the petrochemical sector.

Scenarios for Manpower Allocation - Company " $X$ "

Current Situation

Premises

\section{Technological}

» The unit operation is automated, computer controlled (SDCD).

» There are 2 independent consoles (SDCD control panels) to control the productive process.

» There is medium automation level in the area. Many maneuvers are still manual.

\section{Organisational}

»Operation is conducted in 3 shifts. There are 5 operation groups.

» There is a task division between "Business Hours Team" (BHT) and the teams working in shifts: the administrative support and communication activities with other areas of the company are attributions allocated to BHT and not to the shift teams.

» Work allocation in the current scenario foresees operation in normal situation. In case of emergency, the team and technical support have to be reinforced.

3. Related to the Knowledge in the Cooperation

»Competence level/ experience are not homogeneous among operators. The reallocation of the operators within the team is defined by the supervision.

» The lead time for a newly employed operator to be able to take on a responsibility position in the operation requires training that varies between 6 months to 1.5 year.

Scenario 1: Current Organisational Chart (Figure 2) 
Figure 2 - Current Organisational Chart

\begin{tabular}{|c|c|c|}
\hline \multicolumn{3}{|c|}{ Business Hours Team } \\
\hline \multicolumn{3}{|c|}{ Manager } \\
\hline $\begin{array}{l}\text { 2 Process } \\
\text { Engineers }\end{array}$ & $\begin{array}{c}\text { 1 Maintenance } \\
\text { Technician }\end{array}$ & 1 Assistant \\
\hline
\end{tabular}

\begin{tabular}{|c|c|c|c|c|c|}
\hline \multicolumn{6}{|c|}{ Shifts Teams } \\
\hline Functions & Team 1 & Team 2 & Team 3 & Team 4 & Team 5 \\
\hline Supervision & $\begin{array}{c}1 \text { Operator } \\
\text { Experienced }\end{array}$ & $\begin{array}{c}1 \text { Operator } \\
\text { Experienced }\end{array}$ & $\begin{array}{c}1 \text { Operator } \\
\text { Experienced }\end{array}$ & $\begin{array}{c}1 \text { Operator } \\
\text { Experienced }\end{array}$ & $\begin{array}{l}1 \text { Operator } \\
\text { Experienced }\end{array}$ \\
\hline SDCD Operator & $\begin{array}{c}2 \text { Operator } \\
\text { Experienced }\end{array}$ & $\begin{array}{c}2 \text { Operator } \\
\text { Experienced }\end{array}$ & $\begin{array}{c}2 \text { Operator } \\
\text { Experienced } \\
\end{array}$ & $\begin{array}{c}2 \text { Operator } \\
\text { Experienced } \\
\end{array}$ & $\begin{array}{l}2 \text { Operator } \\
\text { Experienced }\end{array}$ \\
\hline Area I Operator & $\begin{array}{c}1 \text { Operator } \\
\text { Beginner } \\
\end{array}$ & $\begin{array}{c}1 \text { Operator } \\
\text { Beginner } \\
\end{array}$ & $\begin{array}{c}1 \text { Operator } \\
\text { Beginner } \\
\end{array}$ & $\begin{array}{c}1 \text { Operator } \\
\text { Beginner }\end{array}$ & $\begin{array}{c}1 \text { Operator } \\
\text { Beginner }\end{array}$ \\
\hline Area II Operator & $\begin{array}{l}1 \text { Operator } \\
\text { Beginner }\end{array}$ & $\begin{array}{c}1 \text { Operator } \\
\text { Beginner }\end{array}$ & $\begin{array}{c}1 \text { Operator } \\
\text { Beginner }\end{array}$ & $\begin{array}{c}1 \text { Operator } \\
\text { Beginner }\end{array}$ & $\begin{array}{c}1 \text { Operator } \\
\text { Beginner }\end{array}$ \\
\hline $\begin{array}{l}\text { Reserve Team } \\
\text { (Coverage for absence) }\end{array}$ & $\begin{array}{c}2 \text { Operator } \\
\text { Beginner }\end{array}$ & $\begin{array}{c}2 \text { Operator } \\
\text { Beginner }\end{array}$ & $\begin{array}{c}2 \text { Operator } \\
\text { Beginner }\end{array}$ & $\begin{array}{c}2 \text { Operator } \\
\text { Beginner }\end{array}$ & $\begin{array}{c}2 \text { Operator } \\
\text { Beginner }\end{array}$ \\
\hline
\end{tabular}

Source: Created by authrs, from research data

This scenario contemplates 5 people in the BHT - 1 Manager, 2 Process Engineers, 1 Maintenance Technician and 1 Administrative Assistant - and 35 people working in shifts.

Analysis of the Current Scenario (Table 1)

Table 1 - Analysis of Current Scenario

\begin{tabular}{|l|l|l|}
\hline Indicators & Analysis & Developments \\
\hline $\begin{array}{l}\text { Ability to conduct inspections } \\
\text { and (area) readings and/or } \\
\text { panel procedures }\end{array}$ & $\begin{array}{l}\text { The operator of area I cannot } \\
\text { accomplish all his tasks within the } \\
\text { shift. Normally, inspections and } \\
\text { product sampling are delayed. }\end{array}$ & $\begin{array}{l}\text { There may be malfunctioning of } \\
\text { equipments due to lack of adequate } \\
\text { inspection. } \\
\text { Lack of laboratory analysis may } \\
\text { undercover severe process problems. }\end{array}$ \\
\hline Volume of overtime work & $\begin{array}{l}\text { On average, each operator works } \\
\text { considered excessive by the } \\
\text { company), to cover vacations, training } \\
\text { and absences. }\end{array}$ & $\begin{array}{l}\text { The operation excessively depends on } \\
\text { overtime work. }\end{array}$ \\
\hline $\begin{array}{l}\text { Availability for developing } \\
\text { individual/ collective } \\
\text { competencies }\end{array}$ & $\begin{array}{l}\text { Operation focused on routine } \\
\text { activities- time for updating, reading } \\
\text { and training is reduced. } \\
\text { free time. } \\
\text { Time of training procedures, } \\
\text { technical courses and learning by } \\
\text { doing training in the console is of, } \\
\text { approximately, w hh/year. }\end{array}$ & $\begin{array}{l}\text { Need to make operational training } \\
\text { viable to allow for the flexibility of OP } \\
\text { and for continuous qualification of less } \\
\text { experienced supervisors and operators } \\
\text { to compensate turnover. } \\
\text { Current need for training - corporative, } \\
\text { procedure updating, technical courses } \\
\text { and learning by doing training in } \\
\text { console - is approximately y hh/year. }\end{array}$ \\
\hline
\end{tabular}




\begin{tabular}{|c|c|c|}
\hline $\begin{array}{l}\text { Availability for proposing } \\
\text { innovations (improvement } \\
\text { in process, procedures and } \\
\text { others) }\end{array}$ & $\begin{array}{l}\text { Operation focused on operational } \\
\text { continuity. Innovations and } \\
\text { process improvements are the BHT } \\
\text { personnel's role. }\end{array}$ & $\begin{array}{l}\text { Process engineers have little availability } \\
\text { of time for proposing innovations and } \\
\text { improvements in processes, as they } \\
\text { are involved in other projects at the } \\
\text { company and only pay attention to solve } \\
\text { operational problems in short term. } \\
\text { Verify viability/need to involve OPs in } \\
\text { these activities. }\end{array}$ \\
\hline Organizational atmosphere & $\begin{array}{l}\text { Excess of work and overtime causes } \\
\text { dissatisfaction among the operational } \\
\text { staff. }\end{array}$ & $\begin{array}{l}\text { Dissatisfaction has been increasing } \\
\text { "turnover" year after year. About } \mathbf{n} \\
\text { people a year resign or get transferred, } \\
\text { increasing the need for new operators } \\
\text { training time and qualification. }\end{array}$ \\
\hline $\begin{array}{l}\text { Operational safety and } \\
\text { occupational health }\end{array}$ & $\begin{array}{l}\text { Overtime and training during free } \\
\text { time has decreased resting time. }\end{array}$ & $\begin{array}{l}\text { Increased probability of human fault } \\
\text { during operation. }\end{array}$ \\
\hline $\begin{array}{l}\text { Impact on the Benefit/ Cost } \\
\text { Relation in the scenario }\end{array}$ & & Does not apply. \\
\hline
\end{tabular}

Souce: Created by authors

Relevant points to be treated in the scenarios presented as an alternative to the current one:

» Non-compliance with Operational routine in the area

» High Volume of Overtime

» Time Availability for training

» Organizational Atmosphere- Dissatisfaction

» Little involvement of operators in proposing innovations and solutions to problems

\section{Alternative Scenario 1}

Goals

» Full compliance with the area routines

» Increasing time availability for training.

» Reducing overtime to cover for vacations and absences.

» Improving organizational atmosphere

» Involving operators in innovation activities
Revised Premises (note that of the 3 groups of premises, those concerning "Technological" were not modified in relation to what can be observed in the current scenario, reason why they are not mentioned below)

\section{Organizational}

» Flexibility in the functions for area operators

» Operators and supervisors participate in continuous improvement projects and in the solution of problems, together with Process Engineers.

» Addition of 1 Operator in each shift, in the "Reserve Team", to cover for absences due to training, vacations, illness, etc.

3. Knowledge

» On the job training for supervisors and operators, conducted during BHT, with exclusive dedication, that is, without operation responsibilities.

»Continuous training and improvement of operators, aiming at the replacement of workers due to retirements and dismissal. 
Organisational Chart in Alternative Scenario 1 (Figure 3)

Figure 3 - Alternative Scenario 1 Organisational Chart

\begin{tabular}{|c|c|c|}
\hline \multicolumn{3}{|c|}{ Business Hours Team } \\
\hline \multicolumn{3}{|c|}{ Manager } \\
\hline $\begin{array}{l}\text { 2 Process } \\
\text { Engineers }\end{array}$ & $\begin{array}{c}\text { 1 Maintenance } \\
\text { Technician }\end{array}$ & 1 Assistant \\
\hline
\end{tabular}

\begin{tabular}{|c|c|c|c|c|c|}
\hline \multicolumn{6}{|c|}{ Shifts Teams } \\
\hline Functions & Team 1 & Team 2 & Team 3 & Team 4 & Team 5 \\
\hline Supervision & $\begin{array}{l}1 \text { Operator } \\
\text { Experienced }\end{array}$ & $\begin{array}{l}1 \text { Operator } \\
\text { Experienced }\end{array}$ & $\begin{array}{l}1 \text { Operator } \\
\text { Experienced }\end{array}$ & $\begin{array}{l}1 \text { Operator } \\
\text { Experienced }\end{array}$ & $\begin{array}{l}1 \text { Operator } \\
\text { Experienced }\end{array}$ \\
\hline SDCD Operator & $\begin{array}{l}2 \text { Operator } \\
\text { Experienced }\end{array}$ & $\begin{array}{l}2 \text { Operator } \\
\text { Experienced }\end{array}$ & $\begin{array}{l}2 \text { Operator } \\
\text { Experienced }\end{array}$ & $\begin{array}{l}2 \text { Operator } \\
\text { Experienced }\end{array}$ & $\begin{array}{l}2 \text { Operator } \\
\text { Experienced }\end{array}$ \\
\hline Area I Operator & $\begin{array}{l}\text { 1 Operator } \\
\text { Beginner }\end{array}$ & $\begin{array}{l}\text { 1 Operator } \\
\text { Beginner }\end{array}$ & $\begin{array}{l}\text { 1 Operator } \\
\text { Beginner }\end{array}$ & $\begin{array}{l}\text { 1 Operator } \\
\text { Beginner }\end{array}$ & $\begin{array}{l}\text { 1 Operator } \\
\text { Beginner }\end{array}$ \\
\hline Area II Operator & $\begin{array}{l}\text { 1 Operator } \\
\text { Beginner }\end{array}$ & $\begin{array}{l}\text { 1 Operator } \\
\text { Beginner }\end{array}$ & $\begin{array}{l}\text { 1 Operator } \\
\text { Beginner }\end{array}$ & $\begin{array}{l}\text { 1 Operator } \\
\text { Beginner }\end{array}$ & $\begin{array}{l}\text { 1 Operator } \\
\text { Beginner }\end{array}$ \\
\hline $\begin{array}{l}\text { Reserve Team } \\
\text { (Coverage for absence) }\end{array}$ & $\begin{array}{l}3 \text { Operator } \\
\text { Beginner }\end{array}$ & $\begin{array}{l}3 \text { Operator } \\
\text { Beginner }\end{array}$ & $\begin{array}{l}3 \text { Operator } \\
\text { Beginner }\end{array}$ & $\begin{array}{l}3 \text { Operator } \\
\text { Beginner }\end{array}$ & $\begin{array}{l}3 \text { Operator } \\
\text { Beginner }\end{array}$ \\
\hline
\end{tabular}

Source: Created by authors

Analysis of Alternative Scenario 1 (Table 2)

Table 2 - Analysis of Alternative Scenario 1

\begin{tabular}{|l|l|}
\hline \multicolumn{1}{|c|}{ Indicators } & \multicolumn{1}{c|}{ Potential Impacts of Manpower Allocation } \\
\hline $\begin{array}{l}\text { Ability for making inspections } \\
\text { and (area) readings and/or panel } \\
\text { procedures }\end{array}$ & $\begin{array}{l}\text { With flexibility of functions among area operators, there is } \\
\text { availability of time to comply with the whole of the inspections } \\
\text { and samplings routine. }\end{array}$ \\
\hline Volume of overtime & $\begin{array}{l}\text { With an extra operator to cover for workers on vacation and } \\
\text { absentees, there is a reduction in overtime per operator. }\end{array}$ \\
\hline $\begin{array}{l}\text { Ability and availability for } \\
\text { developing individual/ collective } \\
\text { competencies }\end{array}$ & $\begin{array}{l}\text { With an extra operator to cover for workers on vacation and } \\
\text { absentees, there is time availability for training in AT, without } \\
\text { the need to generate Overtime to make training viable. }\end{array}$ \\
\hline $\begin{array}{l}\text { Ability and availability } \\
\text { for proposing innovations } \\
\text { (improvement of process, } \\
\text { procedures and others) }\end{array}$ & $\begin{array}{l}\text { Involvement of operators and supervisors in projects for } \\
\text { improving processes provides greater development of } \\
\text { individual competencies. }\end{array}$ \\
\hline & $\begin{array}{l}\text { With more training, greater involvement of operators in } \\
\text { innovation, in improvement projects and reduction of overtime, } \\
\text { there may be an increase in satisfaction and potential reduction } \\
\text { in resignations. }\end{array}$ \\
\hline $\begin{array}{l}\text { Organizational atmosphere } \\
\text { health }\end{array}$ & $\begin{array}{l}\text { Respect to resting time and reduction of Overtime reduces } \\
\text { operators' fatigue and accident risks. }\end{array}$ \\
\hline
\end{tabular}


Impact on the Benefit/ Cost Relation in the scenario
There is an increase of 5 operators, representing an increase by $15 \%$ in the labour cost, but there is significant reduction in the cost of overtime (which is paid with an additional value).

Greater availability of time for training allows accelerating the qualification process of less experienced operators and reduces negative impacts of turnover on the team.

Source: Created by authors

The application of the method proposed would go on from this point with the following activities:

- Development of a larger number of scenarios as alternatives to the existing one.

- Analysis of these scenarios, identifying their impacts from the point of view of the indicators chosen to analyze them.

- Presentation of all scenarios, both the current and the alternative ones, to the managers group, assessment of each of them in order to decide on which scenario would be the most suitable or whether it is still the case for generating other scenarios, possibly a combination of the ones already generated. This is the phase in which the different visions of the actors involved in this decision must emerge, turn explicit and be the target of discussion, negotiation and, possibly, of consensus. The building of a new scenario may be necessary or even a revision of the indicators chosen.

\section{CONCLUSIONS: MERITS AND RESTRICTIONS OF THE METHODOLOGY PROPOSED}

In the development of this work, it was clear that the use of T\&M methods does not apply to continuous and complex processes (as the process of the company where the research was conducted), since these methods do not take into account the different factors affecting work allocation and do not consider the specificities of the type of work conducted in this process. Above all, being an issue with strong political implications, it is not likely to be only technically solved.

This article sought to contribute to the lack of literature and of structured methods on the theme, starting from a presupposition that it is necessary to develop a method that organizes information, as much as possible explicit the premises and the consequences that the decisions on work allocation might cause. One of the main possible merits of this method is to make explicit the critical decisions concerning work allocation, as it takes into consideration the different factors and the different points of view (lower staff, managing staff) that interfere and are affected by this decision. Another possible merit is the use of alternative scenarios, which allows for discussing the planning of the operation as a whole, by means of using a tool that induces the collective discussion of the variables and alternative ways for organizing the operation.

The application of the method in the company in question showed the importance that has to be given to the speed at which the adequate competencies can be mobilized to deal with the so-called "events", typical of any operation, but that are critical in environments marked by continuous and complex processes. The opportunity cost of not being able to count on the number of operators and the respective adequate qualification for dealing with "events" is a fundamental aspect that has to be considered in the analysis of the efficiency of modern operation systems. Moreover, the case under analysis showed how a decision of increasing personnel may be hindered by the lead time necessary for complete training operators to be able to do all the work, specially those considered more complex: In typical continuous processes environments, there is an "inertia" inherent to the process of increasing personnel, a characteristic that cannot be left aside in a decision of this nature. The decision taken today will have strong implications on future changes.

The authors have also considered the importance (and the possibility) of the replicability of this methodology in others situations, companies or even different problems: the conclusion here, after a series of discussions with students, managers and researchers is that it can be successfully utilized in different situations, especially when one faces the problem of decision making in complex systems and situations. The main advantage here is, as stressed before, the 
potential of this methodoly to organize and evaluate different solutions to the problem that does not have and obvious or best solution.

Nevertheless, the methodology proposed also presents some restrictions: its application depends on mobilization of different actors and of an internal disposition of the organization to simultaneously decide on different variables. Furthermore, as it demands discussion and search for a consensus among the different parts involved, its application could take time and be tiresome, mainly in complex environments in the different meanings of the word.

As a pioneer work on an alternative method for decision support of work allocation in complex production processes, a new front emerges for further researches in the area, for discussing and improving the method, its applicability to other types of activities and processes, specially those requiring predominantly intellectual and intensive work in terms of knowledge.

\section{REFERENCES}

Barnes, R.M. (1980). Motion and Time Study - Design and Measurement of Work, Chichester: John Wiley and Sons.

Brennan L. and Orwig, R. (2000). A Tale of Two Heuristics: Conflict Work Allocation Approaches in Engineering Consulting. Engineering Management Journal,12 (3): 18-25.

Buchanan, D. and Bessant, J. (1985). Failure, Uncertainty and Control: The Role of Operators in a Computer Integrated Production System, Journal of Management Studies, 22 (3): 292-308.
Coughlan, P. and Coghlan, D. (2002). Action Research for Operations Management. International Journal of Operations and Production Management, 22 (2): 220-240.

Daniellou, F. (1995) La construction sociale de et par l'analyse du travail. Performances Humaines et Techniques, num. especial, 25:29, Université de Bordeaux II.

Khurana, A. (1999). Managing Complex Production Processes. Sloan Management Review, 40 (2): 85-97.

Knapp, G.M. and Mahajan, M. (1998). Optimization of Maintenance Organization and Manpower in Process Industries. Journal of Quality in Maintenance Engineering, 4 (3): 168-183.

Mintzberg. H. Managing (2009). New York: Berrer-Koehler.

Morgan, G. (1997). Images of Organizations. Thousand Oaks : Sage.

Taylor, F.W. (1947). Principles of Scientific Management. New York: Harper.

Toledo, J.C., Ferro, J.R. and Truzzi, O.M.S. Indústrias de Processos Contínuos: Novos Rumos para a Organização do Trabalho. Revista Administração de Empresas, 26,(1): 103-105.

Van Der Heijden, K. (1996). Scenarios: The art of Strategic Conversation. Chichester: John Wiley and Sons.

Woodward, J. (1965). Industrial Organizations: theory and practice. New York: Oxford University Press.

Yeh, L., Lan, T. and Gaung, L. (2005). A model of optimal manpower allocation for chiphandling in manufacturing. International Journal of Computer Applications in Technology, 24 (1): 49-54.

Zarifian, P. (1994). Travail collectif et modèles d'organisation de la production. Le Travail Humain, 57 (3): 239-249.

\section{AUTHOR'S BIOGRAPHY}

Adriana Marotti de Mello is Professor in Operations Management for the Business Administration course in the School of Economics, Business and Accounting at the University of São Paulo. She holds Chemical Engineering degree (Polytechnic School of University of São Paulo, 1993). She has a PhD degree (2010) and is M.Sc. in Production Engineering(2006) from Polytechnic School of University of São Paulo.

Roberto Marx is Professor at Polytechnic School, University of São Paulo - USP . He holds Production Engineering degree (Polytechnic School of University of São Paulo, 1980). He is M.Sc.(1987) and Ph.D (1996) in Production Engineering from Polytechnic School of University of São Paulo. He was Visiting Fellow at IDS - Institute of Development Studies - University of Sussex (1992-1993).

Mauro Zobovicius is Professor at Polytechnic School, University of São Paulo - USP . He holds Production Engineering degree (Polytechnic School of University of São Paulo, 1980). He is M.Sc.(1987) and Ph.D (1997) in Production Engineering from Polytechnic School of University of São Paulo 